\title{
Pengaruh Model Pembelajaran Inkuiri Terbimbing dalam Pembelajaran Biologi Bermuatan Kearifan Lokal terhadap Keterampilan Proses Sains dan Karakter
}

\author{
I G N Yuda Pranata ${ }^{1}$, I B Putu Arnyana ${ }^{2}$ \\ ${ }^{12}$ Jurusan Pendidikan IPA Program Studi Pasca Sarjana \\ Universitas Pendidikan Ganesha, Singaraja, Indonesia \\ e-mail: yuda.pranata@undiksha.ac.id ${ }^{1}$, putu.arnyana@undiksha.ac.id ${ }^{2}$
}

\begin{abstract}
Abstrak
Penelitian ini bertujuan untuk menganalisis: (1) perbedaan keterampilan proses sains dan karakter siswa antara kelompok siswa yang belajar dengan inkuiri terbimbing dan kelompok siswa yang belajar dengan model pengajaran langsung, (2) perbedaan keterampilan proses sains antara kelompok siswa yang belajar dengan inkuiri terbimbing dan kelompok siswa yang belajar dengan model pengajaran langsung, (3) perbedaan karakter siswa antara kelompok siswa yang belajar dengan inkuiri terbimbing dan kelompok siswa yang belajar dengan model pengajaran langsung.Jenis penelitian ini merupakan eksperimen semu dengan rancangan non equivalent postest only control group design. Populasi dalam penelitian ini berjumlah304 siswa dan sampel penelitian yang digunakan adalah 76 siswa. Data dikumpulkan dengan tes keterampilan proses sains dan lembar observasi karakter siswa. Data yang diperoleh dianalisis dengan analisis deskriptif dan analisis statistik menggunakan analisis MANOVA. Hasil penelitian ini menunjukkan bahwa.(1) terdapat perbedaan yang signifikan dalam hal keterampilan proses sains dan karakter siswa antara kelompok siswa yang belajar dengan model inkuiri terbimbing dan siswa yang belajar dengan model pengajaran langsung $(F=1,114$; $p<0,05)$, (2) terdapat perbedaan yang signifikan dalam hal keterampilan proses sains antara siswa yang belajar dengan inkuiri terbimbing dan kelompok siswa yang belajar dengan model pengajaran langsung $(F=8,443 ; p<0,05)$, (3) terdapat perbedaan yang signifikan dalam hal karakter siswa antara siswa yang belajar dengan inkuiri terbimbing dan kelompok siswa yang belajar dengan model pengajaran langsung $(F=223,287 ; P<0,05)$, selanjutnya analisis LSD menunjukkan bahwa model pembelajaran inkuiri terbimbing lebih unggul dibandingkan dengan model pengajaran langsung baik dalam keterampilan proses sains dan karakter siswa.
\end{abstract}

Kata kunci: Model Pembelajaran Inkuiri Terbimbing, Keterampilan Proses Sains dan Krakter siswa

\section{Abstract}

This research aimed to analyze: (1) difference science skill process and learners character between learners group who studied with guiding inquiry model and learners group who studied with direct instruction model, (2) difference science process skill between learners group who studied with guiding inquiry model and learners group who studied with direct instruction model, (3) difference learners character between learners group who studied with guiding inquiry model and learners group who studied with direct instruction model. This research was Quasi Experiment with non equivalent posttest only control group design. The populations of this research were 304 learners, and the samples of this research that were used 76 learners. Data collected process was done by test of science process skill and paper of learner character observation. Data analyzed by descriptive analyze and statistic analyze by MANOVA. The results of this research viewed as follows. (1) There was significantly difference of science process skill and learners character between learners group who studied with guiding inquiry model and learners group who studied with direct instruction model $(F=1,114 ; p<0.05)$, (2) There was significantly difference of science skill process between learners group who studied with guiding inquiry model and learners group who studied with direct instruction model $(F=8,443 ; p<0.05)$, (3) There was significantly difference of learners character between learners group who studied with guiding inquiry model and learners group who studied with direct instruction model $(F=223,287 ; P<0.05)$, furthermore, analyze of $L S D$ viewed that guiding inquiry model better than direct instruction model based on science process skill and learners character.

Keywords: Guiding Inquiry Learning, Science Skill Process, and Learners Character 


\section{Pendahuluan}

Pendidikan merupakan sarana untuk menciptakan sumber daya manusia yang berkualitas, berbudaya dan memiliki sikap keselarasan dengan alam. Pendidikan bukanlah sesuatu yang dinamis melain pendidikan adalah suatu hal yang statis (Ambarsari., dkk, 2013). Untuk mencapai tujuan tersebut, pemerintah telah berupaya melalui penetapan berbagai peraturan untuk menjamin agar setiap warga negara memperoleh pendidikan yang berkualitas (Hermawati, 2012). Sejalan dengan hal tersebut, pendidikan harus mampu membelajarkan dan mengembangkan potensi keterampilan yang dimiliki oleh siswa, sehingga siswa mampu menerapkan keilmuan yang dimiliki untuk menghadapi persaingan dan permasalahan pada kehidupan mereka. Secara formal sistem pendidikan Indonesia diarahkan pada tercapainya cita-cita pendidikan yang ideal dalam rangka mewujudkan peradaban bangsa Indonesia yang bermartabat (UU No. 20 Tahun 2003 tentang SISDIKNAS). Tercapainya cita-cita pendidikan akan melahirkan generasi yang memiliki sikap beriman dan bertaqwa kepada Tuhan Yang Maha Esa, berakhlak mulia, sehat, berilmu, cakap, kreatif, mandiri, berdaya saing menjadi warga negara yang demokratis dan bertanggung jawab.

Namun hingga saat ini masih saja di temukan permasalahan-permasalahan pendidikan. Hal senada juga diungkapkan oleh Hermawati (2012) pembangunan pendidikan yang diselenggarakan sekarang nampaknya dapat diakui bersama belum mendapatkan hasil yang sesuai dengan harapan. Salah satu penyebab hasil dari sebuah pendidikan belum sesuai harapan adalah cara mengajar yang masih di dominasi oleh guru dalam menjelaskan materi di dalam kelas. Apalagi pelajaran yang di ajarkan adalah pelajaran biologi yang cenderung dalam bentuk hafalan. Pembelajaran biologi di sekolah kebanyakan masih didominasi dengan cara yang konvensional, sehingga siswa cepat menjadi jenuh dalam berpikir dan ini akan menyebabkan pembelajaran menjadi kurang efektif. Yuniastuti (2013) menyatakan bahwa pelajaran biologi masih diajarkan dengan sistem hafalan sehingga kurang mengembangkan proses berpikir. Seharusnya, pembelajaran biologi yang baik ialah pembelajaran yang dilandaskan pada prinsip keterampilan proses, di mana siswa dididik untuk menemukan dan mengembangkan sendiri fakta dan konsepnya sendiri (Yuniastuti, 2013).

Dimyati dan Moedjiono (2015), ada berbagai keterampilan proses, keterampilanketeramilan tersebut terdiri dari keterampilan dasar proses sains (basic skill), dimulai dari mengobservasi, mengklasifikasi, memprediksi, mengukur, menyimpulkan dan mengkomunikasikan, dan keterampilan terpadu proses sains (integrated skill), dari identifikasi variabel sampai dengan yang paling kompleks, yaitu eksperimen. Biologi termasuk dalam bidang kajian ilmu sains dan juga sangat berkaitan dengan inkuiri secara sistematis, sehingga pembelajaran bukan hanya sebagai penguasaan kumpulan pengetahuan yang berupa faktafakta, konsep-konsep tau prinsip-prinsip saja, tetapi juga sebagai suatu proses penemuan (Warianto, 2011). Inkuiri menurut Gulo (2004); Ambarsari., dkk, (2013) berarti suatu rangkaian kegiatan belajar yang melibatkan secara maksimal seluruh kemampuan siswa untuk mencari dan menyelidiki secara sistematis, kritis, logis, analitis, sehingga mereka dapat merumuskan sendiri penemuannya dengan penuh percaya diri. Arnyana (2011) memaparkan bahwa pembelajaran dengan pendekat inkuiri sangat terintegrasi meliputi penerapan proses sains yang menerapkan proses berpikir logis dan kritis.

Suchman (1996); Hermawati (2012) memperkuat keyakinan ini dengan mengatakan bahwa inkuiri merupakan alat fundamental bagaimana anak belajar, karena pembelajaran sains (biologi) tidak dapat dijalankan tanpa melalui inkuiri. Keunggulan inkuiri dalam pembelajaran biologi didukung oleh pernyataan Bruner; Amin, (1987); Hermawati, (2012) yang menyatakan keuntungan mengajar dengan model inkuiri adalah : (1) siswa akan memahami konsep-konsep dasar dan ide-ide yang lebih baik, (2) membantu siswa dalam menggunakan daya ingat dan transfer pada situasi-situasi proses belajar yang baru, (3) mendorong siswa untuk berpikir dan bekerja atas inisiatif sendiri, dan (4) mendorong siswa berpikir inisiatif dan merumuskan hipotesanya sendiri. Salah satu dari inkuiri yang dapat digunakan untuk menanamkan keterampilan proses sains adalah inkuiri terbimbing. Dengan inkuiri terbimbing dapat membantu mengembangkan kemampuan mengamati, menggolongkan /mengklasifikasikan, menaksir/ menginterpretasikan, meramalkan, menerapkan, merencanakan penelitian, mengkomunikasikan.

Inkuiri terbimbing terbilang suatu model yang tepat untuk membelajarkan biologi. Selain itu dalam penelitian ini pemebalajaran biologi juga diintegrasikan dengan kearifan lokal, dengan tujuan untuk menanamkan pendidikan karakter disamping keterampilan proses sains. Kearifan lokal atau sering disebut local wisdom dapat dipahami sebagai usaha manusia dengan 
menggunakan akal budinya (kognisi) untuk bertindak dan bersikap terhadap sesuatu, objek, atau peristiwa yang terjadi dalam ruang tertentu (Khusniati, 2014). Warigan (2011) menyatakan dalam setiap jengkal hidup manusia selalu ada kearifan lokal, paling tidak kearifan dapat muncul pada (a) pemikiran, (b) sikap, dan (c) perilaku dan ketiganya hampir sulit untuk dipisahkan. Dengan demikian kearifan lokal dalam pembelajaran dapat digunakan untuk menanamkan pendidikan karakter pada siswa.Dengan model pembelajaran inkuiri terbimbing yang diterapkan pada pelajaran biologi bermuatan kearifan lokal, dapat menanamkan ketiga komponen aspek pada kurikulum 2013. Berdasarkan hasil penelitian Praptiwi (2012); Akhlis dan Dewi (2014), inkuiri mampu meningkatkan unjuk kerja (aktivitas) peserta didik dalam pembelajaran. Selain itu inkuiri termasuk pembelajaran active learning yang dapat menanamkan sikap dan perilaku pada siswa selain knowledge. Melihat dari permasalahan di atas maka yang akan di kaji adalah bagaimana pengaruh model pembelajaran inkuiri terbimbing dalam pembelajaran biologi bermuatan kearifan lokal terhadap keterampilan sains dasar dan karakter siswa di SMP.

\section{Metode}

Penelitian ini merupakan penelitian eksperimen semu (quasi experiment). Menurut Sugiyono (2014), eksperimen semu (quasi experimental) merupakan jenis penelitian yang mempunyai kelompok kontrol, tetapi tidak dapat berfungsi sepenuhnya mengontrol variabelvariabel luar yang mempengaruhi hasil penelitian. Rancangan penelitian yang digunakan adalah non equivalent postest only control group design. Populasi dalam penelitian ini adalah menggunakan seluruh kelas VII yang ada di SMP N 1 Gianyar tahun ajaran 2015/2016, yang berjumlah 8 kelas, dengan jumlah siswa 304 orang yang terdistribusi dalam kelas-kelas yang homogen secara akademik. Sebelum digunakan sebagai sampel penelitian kelas terlebih dahulu harus diuji kesetaraannya untuk mengetahui bahwa kelas yang digunakan sebagai sampel adalah kelompok siswa yang memiliki kemampuan yang setara antara kelas satu dengan yang lainnya. Uji kesetraan menggunakan spss 16.0 for windows Sampel diambil dengan cara simple random sampling, yaitu pemilihan sampel dari populasi dilakukan secara acak tanpa memperhatikan strata yang ada dalam populasi. Kelas yang digunakan sebagai sampel dalam penelitian ini adalah kelas VIIB dan VIIC. Berdasarkan hasil pengundian juga diperoleh hasil kelas VIIB terpilih sebagai kelompok eksperimen, dimana kelas tersebut diberi perlakuan model pembelajaran inkuiri terbimbing. Kelas VIIC terpilih sebagai kelas kontrol, dimana kelas tersebut diberi perlakuan model pengajaran langsung.

Variabel bebas dalam penelitian yaitu model pembelajaran inkuiri terbimbing. Sedangkan variabel terikat dalam penelitian ini yaitu keterampilan proses sains dan karakter siswa. Data pada penelitian ini ada dua yakni keterampilan proses sains dan karakter siswa. Data mengenai keterampilan proses sains dikumpulkan menggunakan tes keterampilan proses sains dengan. Sedangkan data mengenai karakter siswa dikumpulkan dengan menggunakan lembar observasi karakter. Pembuatan instrumen dalam penelitian ini, terlebih dahulu disusun kisikisi instrumen. Kisi-kisi hasil belajar disusun dengan berpedoman pada kurikulum yang ada yakni kurikulum 2013 menyangkut kompetensi inti, kompetensi dasar, aspek materi dan indikatornya. Kisi-kisi instrumen keterampilam proses sains indikatornya diambil dari Nurohman (2010). Sedangkan untuk karakter diadopsi dari Kemendiknas. Sebelum instrumen digunakan, terlebih dahulu dilakukan judgment oleh dua orang dosen untuk mendapatkan kualitas tes yang baik. Setelah dilakukan expert judgment maka intrumen akan diujicobakan instrumen. Selanjutnya di uji Konsistensi internal butir, daya beda, tingkat kesukaran, dan reliabilitas. Nilai reliabilitas keterampilan proses sains sebesar 0,73 yang tergolong tingggi sedangkan untuk karakter sebesar 1,00 yang tergolong sangat tinggi.

Hasil penelitian ini dianalisis dengan analisis deskriptif, uji prasyarat dan uji hipotesis. Hipotesis yang di ajukan dalam penelitian ini adalah (1) Terdapat perbedaan keterampilan proses sains dan karakter siswa yang mengikuti pembelajaran inkuiri terbimbing dan siswa yang belajar dengan model pengajaran langsung. (2) Terdapat perbedaan keterampilan proses sains siswa yang mengikuti pembelajaran inkuiri terbimbing dan siswa yang belajar dengan model pengajaran langsung. (3) Terdapat perbedaan karakter siswa yang mengikuti pembelajaran inkuiri terbimbing dan siswa yang belajar dengan model pengajaran langsung. Pengujian hipotesis menggunakan uji MANOVA daan dilanjutkan dengan uji signifikansi skor rata-rata antar kelompok menggunakan Least Significant Difference (LSD). 


\section{Hasil dan Pembahasan}

Objek dalam penelitian ini adalah keterampilan proses sains dan dan karakter siswa sebagai hasil penerapan model pembelajaran inkuiri terbimbing dan model pengajaran langsung. Ada tiga hal penting yang dibandingkan dalam penelitian ini adalah sebagai berikut. 1) penerapan model pembelajaran inkuiri terbimbing terhadap keterampilan proses sains dan karakter siswa; 2) penerapan model pembelajaran inkuiri terbimbing terdapap keterampilan proses sains; 3) penerapan model pembelajaran inkuiri terbimbing terdapap karakter siswa. Berdasarkan hasil analisis deskriptif keterampilan proses sains siswa yang dibelajar dengan model pembelajaran inkuiri terbimbing memiliki nilai rata-rata sebesar 81,44 dengan nilai maksimum 100 sedangkan nilai minimum 66. Sedangkan untuk kelas yang dibelajarkan dengan model pengajaran langsung nilai rata-ratanya sebesar 75,00 dengan nilai maksimum 94 dan nilai minimum 56. Deskripsi umum data keterampilan proses sains yang belajar dengan model pembelajaran inkuiri terbimbing dan model pengajaran langsung, dapat diindikasikan bahwa secara deskriptif nilai rata-rata kelompok yang dibelajarkan dengan model pembelajaran inkuiri terbimbing lebih tinggi dibandingkan dengan dengan kelompok yang dibelajarkan dengan model pengajaran langsung pada materi ekosistem dan pemanasan global bermuatan kearifan lokal.

Nilai rata-rata krakter siswa kelas eksperimen dengan model pembelajaran inkuiri terbimbing adalah 3,29 , sedangkan nilai rata-rata kelas kontrol dengan model pembelajaran langsung adalah 3,08 . Hasil perhitungan rata-rata menunjukan nilai rata-rata kelas eksperimen lebih besar dibandingkan dengan kontrol. Nilai karakter siswa yang dibelajarkan dengan model pembelajaran inkuiri terbimbing dan model pembelajaran langsung pada materi ekosistem dan pemanasan global bermuatan kearifan lokal, nilai tertinggi dan terendah yang di peroleh siswa kelas eksperimen dengan model pembelajaran inkuiri terbimbing berturut-turut adalah 4 dan 2,70 . Pada kelas yang dibelajarkan dengan model pembelajaran langsung, nilai tertinggi dan terendah secara berturut-turut adalah 3,80 dan 2,20. Hasil penelitian ini tidak hanya berpedoman pada skor rata-rata keterampilan proses sains dan karakter siswa, tetapi juga berpedoman pada skor rata-rata setiap indikator. Berikut merupakan hasil deskripsi penguasaan setiap indikator ditunjukkan pada Tabel 1, Tabel 2 dan Tabel 3 berikut

Tabel 1. Deskripsi Pencapaian Setiap Indikator Keterampilan Proses Sains Pada Kedua Kelompok Perlakuan

\begin{tabular}{|c|c|c|c|c|c|c|}
\hline \multirow[b]{2}{*}{ Indikator } & \multicolumn{3}{|c|}{ MPIT } & \multicolumn{3}{|c|}{ MPL } \\
\hline & Mean & $\begin{array}{c}\text { Konversi } \\
\text { skala } \\
100\end{array}$ & Kategori & Mean & $\begin{array}{c}\text { Konversi } \\
\text { skala } \\
100\end{array}$ & Kategori \\
\hline Mengobservasi & 2,56 & 71,27 & Tinggi & 2,24 & 66,13 & Cukup \\
\hline $\begin{array}{l}\text { Mengajukan } \\
\text { pertanyaan }\end{array}$ & 2,85 & 80,31 & Tinggi & 2,71 & 75,29 & Tinggi \\
\hline Membuat hipotesis & 2,44 & 70,79 & Tinggi & 2,26 & 68,34 & Cukup \\
\hline $\begin{array}{l}\text { Merancang } \\
\text { percobaan }\end{array}$ & 2,22 & 64,16 & Cukup & 2,20 & 63,96 & Cukup \\
\hline Memprediksi & 2,26 & 68,34 & Cukup & 1,93 & 53,72 & Rendah \\
\hline $\begin{array}{l}\text { Mengkomunikasi } \\
\text { kan }\end{array}$ & 2,38 & 70,00 & Tinggi & 2,03 & 56,28 & Cukup \\
\hline
\end{tabular}

Berdasarkan data pada Tabel 1 dapat dijelaskan pada model pembelajaran inkuiri terbimbing pencapaian rata-rata skor untuk setiap indikator keterampilan proses sains. Setiap komponen indikator pada kelompok model pembelajaran inkuiri terbimbing memiliki kualifikasi tinggi dan sedang. Kelompok model pengajaran langsung terlihat bahwa hanya satu indikator yang berkualifikasi tinggi dan empat indikator masuk kategori cukup serta satu indikator masuk kategori rendah. Data diatas menunjukkan bahwa secara keseluruhan setiap indikator penguasaan keterampilan proses sains model pembelajaran inkuiri terbimbing lebih baik dibandingan dengan model pengajaran langsung. Selain pencapaian tiap indikator keterampilan proses sains, diperoleh juga skor pencapaian karakter siswa sebagai berikut. 
IVCEJ, Vol 1 No 1, Tahun 2018

p-ISSN: 2615-4684 e-ISSN: 2615-6938

Tabel 2. Analisis Nilai Rata-Rata Karakter Kelas Kelompok Eksperimen

\begin{tabular}{|c|c|c|c|c|c|c|c|c|c|}
\hline \multirow[t]{2}{*}{ Karakter } & \multicolumn{7}{|c|}{ Hasil observasi ke- } & \multirow{2}{*}{$\begin{array}{l}\text { Rata } \\
\text {-rata }\end{array}$} & \multirow[t]{2}{*}{ Kategori } \\
\hline & 1 & 2 & 3 & 4 & 5 & 6 & 7 & & \\
\hline Kedislipinan & 2,13 & 2,31 & 2,42 & 2,97 & 3,32 & 3,34 & 3,42 & 2,84 & MB \\
\hline Rasa Ingin Tahu & 2,28 & 2,31 & 2,34 & 2,92 & 3,02 & 3,21 & 3,31 & 2,77 & MB \\
\hline Berpikir Logis & 2,15 & 2,28 & 2,39 & 2,92 & 3,05 & 3,13 & 3,21 & 2,73 & MB \\
\hline Jujur & 2,07 & 2,34 & 2,47 & 3,02 & 3,05 & 3,15 & 3,39 & 2,78 & MB \\
\hline Kerjasama & 2,02 & 2,15 & 2,57 & 2,89 & 3,21 & 3,21 & 3,28 & 2,76 & $\mathrm{MB}$ \\
\hline $\begin{array}{l}\text { Tanggung } \\
\text { Jawab }\end{array}$ & 2,07 & 2,23 & 2,68 & 3,10 & 3,21 & 3,26 & 3,36 & 2,84 & MB \\
\hline
\end{tabular}

Keterangan: MB (Mulai Berkembang)

Tabel 3. Analisis Nilai Rata-Rata karakter Kelas Kelompok Kontrol

\begin{tabular}{|c|c|c|c|c|c|c|c|c|c|}
\hline \multirow{2}{*}{ Karakter } & \multicolumn{7}{|c|}{ Hasil observasi ke- } & \multirow{2}{*}{$\begin{array}{l}\text { Rata- } \\
\text { rata }\end{array}$} & \multirow{2}{*}{ Kategori } \\
\hline & 1 & 2 & 3 & 4 & 5 & 6 & 7 & & \\
\hline Kedislipinan & 1,75 & 2,00 & 2,31 & 2,31 & 2,44 & 2,86 & 3,02 & 2,38 & MT \\
\hline Rasa Ingin Tahu & 1,72 & 1,86 & 2,21 & 2,23 & 2,42 & 2,94 & 3,00 & 2,34 & MT \\
\hline Berpikir Logis & 1,51 & 1,68 & 2,28 & 2,31 & 2,44 & 2,92 & 3,10 & 2,32 & MT \\
\hline Jujur & 1,56 & 1,81 & 2,23 & 2,36 & 2,47 & 2,84 & 3,15 & 2,34 & MT \\
\hline Kerjasama & 1,51 & 1,73 & 2,21 & 2,42 & 2,47 & 2,92 & 2,07 & 2,19 & MT \\
\hline $\begin{array}{l}\text { Tanggung } \\
\text { Jawab }\end{array}$ & 1,67 & 1,89 & 2,05 & 2,31 & 2,31 & 2,94 & 3,18 & 2,33 & MT \\
\hline
\end{tabular}

Keterangan, MT (Mulai Terlihat)

Berdasarkan data hasil observasi nilai karakter pada Tabel 2 dan Tabel 3 di atas, nilai setiap aspek karakter siswa kelas eksperimen lebih tinggi dari kelas kontrol pada pertemuan pertama hingga sampai pada pertemuan ke tujuh. Rata-rata nilai karakter kelas eksperimen secara keseluruhan setiap kategori yaitu mulai berkembang (MB), sedangkan nilai rata-rata karakter siswa kelas kontrol secara keseluruhan setiap kategori yaitu mulai terlihat (MT).

Uji prasyarat analisis meliputi uji normalitas data, uji homogenitas varian dan uji kolinieritas antar variabel terikat. Uji prasyarat dilakukan untuk mengetahui sebaran data penelitian yang akan diuji hipotesisnya dan untuk mengetahui ada tidaknya kolineritas. Uji prasyarat dilakukan dengan menggunakan spss 16.00 for windows. Data yang didapat menjadi acuan sebagai analisis uji hipotesis dengan menggunakan analisis multivariat (MANOVA). Uji normalitas dilakukan dengan menggunakan uji statistik Kolmogorov-Smirnov dan Shapiro-Wilk test. Kriteria pengujian yang dilakukan adalah data yang memiliki sebaran distribusi normal jika niali signifikansinya lebih besar dari 0,05 dan jika lebih kecil dari 0,05 atau dalam hal lain data tidak berdistribusi normal. berdasarkan uji statistik Kolmogorov-Smirnov dan Shapiro-Wilk memiliki taraf signifikansi lebih besar dari 0,05 sehingga dapat dikatakan bahwa sebaran data dapat dikatakan berdistribusi normal. Artinya data keterampilan proses sains dan karakter siswa berdistribusi normal pada taraf signifikasi 0,05

Uji homogenitas kelompok yang dibelajarkan dengan model pembelajaran inkuiri terbimbing dan kelompok yang dibelajarkan dengan model pengajaran langsung menggunakan Levene's Test of Equality of Error Variance. Apabila angka signifikasi yang dihasilkan lebih besar dari 0,05, maka varian yang ada adalah homogen. Hasil uji homogenitas untuk keterampilan proses sains dan karakter siswa pada kelompok model pembelajaran inkuiri terbimbing dan model pengajaran langsung menunjukkan angka signifikansi lebih besar dari 0,05 . Karena taraf signifikansinya diatas 0,05 , maka dengan kata lain varian antara kedua kelompok model pembelajaran dapat dikatakan adalah homogen. Uji homogenitas matriks kovarians dilakukan dengan menggunakan uji Box's $M$ test. Matriks kovarians antara variabel terikat dikatakan homogen jika memiliki nilai signifikansi 0,05. nilai signifikansi pada uji Box's $M$ menunjukkan nilai 0,871, dengan demikian nilai signifikasinya lebih tinggi dari pada 0,05 . Hal ini menyatakan bahwa matriks varian antara variabel keterampilan proses sains dan karakter siswa dapat dikatakan homogen. Uji kolinieritas bertujuan untuk mengetahui ada tidaknya korelasi yang signifikan antara variabel. Uji kolinieritas dapat diuji dengan menggunakan product moment dengan bantuan spss 16.00 for windows. Berdasarkan hasil perhitungan 
menunjukan bahwa korelasi Pearson Product Moment $r_{\text {hitung }}=0,673$ dan Sig.(2-tailed) $=0,000$, oleh karena $r_{\text {hitung }}<0,8$ dan Sig.(2-tailed) $<0,05$, maka dapat disimpulkan bahwa tidak hubungan kolinieritas yang signifikan antara variabel keterampilan proses sains dan karakter siswa sehimgga pengujian dengan menggunakan MANOVA dapat dilanjutkan. Uji hipotesis dilakukan dengan menggunakan analisis multivariat (MANOVA) untuk menunjukkan apakah terdapat perbedaan keterampilan proses sains dan karakter siswa antara kelompok model inkuiri terbimbing dengan kelompok model pengajaran langsung dalam pembelajaran biologi bermuatan kearifan lokal. Pada penelitian ini diajukan tiga hipotesis. Pengujian hipotesis yang petama digunakan MANOVA satu jalur, sedangkan untuk pengujian hipotesis kedua dan ketiga digunakan test of between-subjects effects. Pengujian hipotesis dalam penelitian ini dilakukan dengan menggunakan program komputer spss 16.00 for windows.

Hipotesis pertama yang diajukan dalam penelitian ini adalah terdapat perbedaan keterampilan proses sains dan karakter siswa antara kelompok siswa yang belajar dengan model pembelajaran inkuiri terbimbing dan model pengajaran langsung. Berdasarkan hasil pengujian diketahui taraf signifikansi untuk Pillai's Trace, Wilks' Lamda, Hotelling's Trace, Roy's Largest Root dengan $\mathrm{F}=1,114$ dengan taraf signifikasi 0,000 yang berarti $\mathrm{p}<0,05$, dengan demikiandapat diambil keputusan untuk hipotesis pertama adalah terdapat perbedaan keterampilan proses sains dan karakter siswa antara kelompok siswa yang belajar dengan model pembelajaran inkuiri terbimbing dan model pengajaran langsung. Jadi, dengan nilai taraf signifikansi $p<0,05$, maka dapat dikatakan $\mathrm{H}_{0}$ ditolak. Hasil uji hipotesis pertama dapat disimpulkan bahawa terdapat perbedaan keterampilan proses sains dan karakter siswa antara siswa yang belajar dengan model pembelajaran inkuiri terbimbing dan model pengajaran langsung.

Hipotesis kedua yang diajukan dalam penelitian ini adalah terdapat perbedaan keterampilan proses sains siswa antara kelompok model pembelajaran inkuiri terbimbing dan model pengajaran langsung,Berdasarkan rekapitulasi test of between-subjects effects, dapat di paparkan bahwa pengaruh model pembelajran yang di terapkan terhadap keterampilan proses sains, ditunjukkan dengan harga $F=8,443$ dengan nilai signifikasi 0,005 , dimana $p<0,05$, sehingga $\mathrm{H}_{0}$ ditolak. Jadi dapat dikatakan bahwa terdapat perbedaan keterampilan proses sains antara kelompok siswa yang belajar dengan model pembelajaran inkuiri terbimbing dan model pengajaran langsung. Sebagai tindak lanjut atas pengujian hipotesis kedua, maka dilakukan analisis perbedaan skor rata-rata keterampilan proses sains antara kelompok model pembelajan inkuiri terbimbing dan model pengajaran langsung. Nilai rata-rata terestimasi $(\mu)$ dan simpangan baku dari skor keterampilan proses sains. Berdasarkan hasil uji terlihat perbedaan skor rata-rata keterampilan proses sains antara model pembelajaran inkuiri terbimbing dan model pengajaran langsung adalah $\Delta \mu=[\mu(\mathrm{MPIT})-\mu(\mathrm{MPL})]=5,684$ dengan simpangan baku sebesar 1,956 dan nilai signifikansi 0,005. Nilai signifikansi tersebut lebih kecil dari 0,05 . Skor $\Delta \mu$ lebih besar dari batas penolakan LSD sebesar 3,4. Jadi, nilai rata-rata keterampilan proses sains antara kelompok model pembelajaran inkuiri terbimbing dan model pengajaran langsung berbeda secara signifikan pada taraf signifikansi 0,05.

Hipotesis ketiga yang diajukan dalam penelitian ini adalah terdapat perbedaan karakter siswa antara kelompok siswa yang belajar dengan model pembelajaran inkuiri terbimbing dan model pengajaran langsung. Pengujian hipotesis ketiga dengan menggunakan test of betweensubjects effects. $\mathrm{H} 0$ ditolak jika kriteria harga $\mathrm{F}$ memiliki nilai signifikansi lebih kecil dari 0,05. Berdasarkan hasil rekapitulasi test of between-subjects effects, dapat dipaparkan bahwa pengaruh model pembelajaran terhadap karakter siswa dengan nilai $F$ sebesar 223,287 dan memiliki nilai signifikansi sebesar 0,000 . Jadi dapat disimpulkan bahwa nilai signifikansi lebih kecil dari pada 0,05 , sehingga $\mathrm{H} 0$ ditolak, dengan demikian terdapat perbedaan karakter siswa antara kelompok model pembelajaran inkuiri terbimbing dan model pengajaran langsung. Sebagai tindak lanjut dari hipotesis ketiga, selanjutnya dilakukan analisis signifikansi perbedaan skor rata-rata karakter siswa antara kedua kelompok model pembelajaran. Skor rata-rata terestimasi $(\mu)$ dan simpangan baku dari skor karakter siswa kelompok model pembelajaran inkuiri terbimbing dan model pengajaran langsung. Berdasarkan hasil pengujian terlihat perbedaan nilai rata-rata karakter siswa model pembelajaran inkuiri terbimbing dan model pengajaran langsung adalah $\Delta \mu=[(\mathrm{MPIT})-\mu(\mathrm{MPL})]$ sebesar 0,703 dengan simpangan baku 0,047 dan nilai signifikansi sebesar 0,000 . Nilai signifikansi tersebut lebih kecil dari pada 0,05. skor $\Delta \mu$ lebih besar dari pada batas penolakan LSD sebesar 0,08 . Jadi nilai rata-rata karakter siswa antara kelompok model pembelajaran inkuiri terbimbing dan model pengajaran langsung berbeda secara signifikan pada taraf signifikansi 0,05 . 
Pembahasan dalam penelitian ini akan membahas lebih mendalam tentang hasil penelitian dan pengujian hipotesis mengunakan uji MANOVA, Hasil penelitian yang dibahas meliputi 1) perbedaan ketrampilan proses sains dan karakter siswa yang belajar dengan model pembelajaran inkuiri terbimbing dengan model pengajaran langsung, 2) perbedaan keterampilan proses sains siswa yang belajar dengan model inkuiri terbimbing dan dengan model pengajaran langsung, 3) perbedaan karakter siswa yang belajar dengan model pembelajaran inkuiri terbimbing dan dengan model pengajaran langsung. Pembahasan secara mendalam dapat dilihat pada bahasan selanjutnya.

Berdasarkan hasil penelitian yang telah dilakukan, menunjukkan bahwa terdapat perbedaan keterampilan proses sains dan karakter siswa yang signifikan antara kelompok. Model pembelajaran inkuiri terbimbing secara teori dapat memberikan hasil lebih baik terhadap keterampilan proses sains dan karakter siswa, dibandingkan dengan model pengajaran langsung.

Berdasarkan hasil uji menunjukkan bahwa keterampilan proses sains dan karakter siswa berbeda secara signifikan antara kelompok eksperimen dan kelompok kontrol. Hasil penelitian ini sesuai dengan pendapat dari Sadia (2014) yang menyatakan model pembelajaran inkuiri bertujuan untuk melatih kemampuan peserta didik untuk melakukan penelitian, menjelaskan fenomena, menemukan inti dan makna dari suatu permasalahan, dan memecahkan permasalahan melalui prosedur ilmiah yang dilakukan secara mandiri. Model pembelajaran inkuiri terbimbing memiliki beberapa keuntungan yang salah satunya adalah membangun konsep secara mandiri (Self-concept). Hal ini sesuai dengan prinsip dasar keterampilan proses sains dimana peserta didik menemukan suatu konsep atau prinsip dan juga teori, untuk mengembangkan konsep yang sudah ada sebelumnya. Penerapan model pembelajaran inkuiri juga memberikan ruang untuk membiasakan siswa dalam upaya menemukan suatu konsep untuk bersikap kedisiplinan, rasa ingin tahu, berpikir logis, jujur, kerjasama dan tanggung jawab. Hal ini juga didukung oleh Miftakhul., dkk (2012) yang menyatakan bahwa inkuiri terbimbing dapat mengembangkan nilai-nilai karakter kerjasama, disiplin, mandiri, ingin tahu, kerja keras, jujur dan santun. Dalam hal ini model pembelajaran memiliki fungsi ganda yaitu menumbukan keterampilan proses sains dan karakter (sikap) pada siswa.

Model pembelajaran inkuiri memiliki dasar filosofi paham konstruktivisme dimana pengetahuan merupakan konstruksi dari diri sendiri. Peranan guru dalam model pembelajaran inkuiri terbimbing sebagai jembatan dalam pelaksanaan inkuiri.

Dalam proses inkuiri, tahap mengumpulan data merupakan proses mental yang penting dalam pengembangan intelektual (Sadia, 2014). Dalam hal ini guru memiliki peranan sebagai fasilitator, misalnya mengajukan pertanyaan yang dapat membantu siswa untuk menemukan informasi-informasi yang di butuhkan untuk pengujian hipotesis. Memcari informasi dapat membentuk siswa berpikir logis, memiliki rasa ingin tahu dan kerjasama, sehingga data yang diperoleh dapat dipertanggung jawabkan.

Oleh karena itu, siswa harus difokuskan untuk memahami konsep dan prinsip sains sehingga keterampilan proses sains dan karakter akan meningkat. Sedangkan, model pengajaran langsung pada prinsipnya bukan model yang berlandasan konstruktivisme. Jadi peserta didik hanya menerima konsep untuk dipelajari, itulah yang menyebabkan peserta didik cenderung kurang aktif dalam pembelajaran.

Model pengajaran langsung merupakan model pembelajaran yang menitik beratkan pada pendekatan dekduktif untuk mengajarkan dua macam pengetahuan yaitu pengetahuan deklaratif dan pengetahuan prosedural. Model pengajaran langsung menitik beratkan pada kemampuan peserta didik untuk mengolah informasi melalui kegiatan mengamati, mendengarkan dan mencatat. Dengan demikian dominasi guru yang dominan dalam pembelajaran berdampak pada peserta didik untuk mengembangkan keterampilan proses, rasa ingin tahu, berpikir logis dalam mengembangkan pengetahuan yang dimiliki, sehingga berpengaruh terhadap keterampilan proses sains dan karakter peserta didik itu sendiri.

Berdasarkan deskripsi landasan oprasional teoritik tersebut dan dari hasil penelitian, dapat diyakini bahwa model pembelajaran inkuiri terbimbing lebih unggul dibandingkan dengan model pengajaran langsung dalam pencapaian keterampilan proses sains dan karakter. Dalam penelitian ini menunjukan nilai rata-rata model pembelajaran inkuiri terbimbing berkategori baik, sedangkan rata-rata karakter menunjukkan kategori mulai berkembang, sedangkan nilai ratarata kelompok model pembelajaran inkuiri terbimbing lebih tinggi dibandingkan dengan model pengajaran langsung. Berdasarkan uraian diatas dapat disimpulkan bawah model pembelajaran inkuiri terbimbing lebih tepat diterapkan untuk melatih dan menumbuhkan keterampilan proses sains dan karakter dibandingkan dengan model pengajaran langsung. 
Selanjutnya adalah menganalisis perbedaan penerapan model pembelajaran inkuiri terbimbing dan model pengajaran langsung terhadap keterampilan proses sains siswa. Hasil penelitian ini dapat menunjukkan bahwa terdapat perbedaan keterampilan proses sains yang signifikan antara kedua kelompok. Hasil penelitian ini juga didukung oleh penelitian yang dilakukan Ambarsari., dkk (2013) yang menyatakan bahwa penerapan pembelajaran inkuiri terbimbing memberikan pengaruh yang signifikan terhadap ketrampilan proses sains siswa. Tindak lanjut dari pengujian hipotesis kedua dilakukan analasis signifikansi perbedaan skor rata-rata keterampilan proses sains antara kelompok model pembelajaran inkuiri terbimbing dan model pengajaran langsung menggunakan metode Least Significant Difference (LSD). Hasil analsis menunjukkan perbedaan skor rata-rata keterampilan proses sains antara model pembelajaran inkuiri terbimbing dan model pengajaran langsung diperoleh skor rata-rata kedua model berbeda secara signifikan pada taraf signifikansi 0,05. Penelitian ini menunjukkan bahwa model pembelajaran inkuiri terbimbing lebih baik dibandingkan dengan model pengajaran langsung dalam hal mengembangkan dan meningkatkan keterampilan proses sains.

Keterampilan proses sains dalam hal ini merupakan keseluruhan proses ilmiah yang terarah (baik kognitif maupun psikomotor) yang dapat digunakan untuk menemukan suatu konsep atau prinsip dan juga teori, untuk mengembangkan konsep yang telah ada sebelumnya, ataupun melakukan penyangkalan terhadap suatu penemuan (Indrawati; Nuh, 2010). Jadi dengan kata lain penerapan pendekatan keterampilan proses sains melibatkan kemampuan berpikir peserta didik, dengan demikian hal ini dapat digunakan untuk melatih peserta didik mengembangkan konsep yang dimiliki. Selain itu tiap indikator keterampilan proses sains skor rata-rata yang direoleh lebih baik dibandingkan dengan model pengajaran langsung. Hasil penelitian yang dilakukan oleh Suwandri (2015) juga mendapatkan hasil bahwa dengan pencapaian tiap indikator keterampilan proses sains tergolong kriteria tinggi.

Berdasarkan uraian diatas, maka dapat disimpulkan bahwa terdapat perbedaan setiap indikator dari keterampilan proses sains antara kelompok siswa yang belajar dengan model pembelajaran inkuiri terbimbing dan kelompok siswa yang belajar dengan model pengajaran langsung. Jika dibandingkan skor pencapaian setiap indikator keterampilan proses sains antara kelompok model pembelajaran inkuiri terbimbing lebih tinggi dibandingkan dengan skor pencapaian setiap indikator keterampilan proses sains kelompok model pengajaran langsung.

Model pembelajaran inkuiri terbimbing merupakan model pembelajaran yang berlandaskan pada proses untuk memperoleh suatu informasi ilmiah dengan cara melakukan observasi dan dengan bereksperimen yang bertujuan untuk mencari jawaban dari pertanyaan atau memecahkan masalah yang telah dirumuskan dengan menggunakan kemampuan berpikir logis, analitis dan kritis (Sadia, 2014). Guru berfungsi membantu peserta didik dalam untuk mencari informasi dan bereksperimen untuk menemukan jawaban dari pertanyaan atau memecahkan masalah sampai peserta didik menemukan jawaban atas petanyaan yang diajukan sehingga mendapatkan sebuah konsep. Dengan model inkuiri terbimbing keterampilan proses sains akan terlaksana dengan baik. Berbeda dengan model pengajaran langsung, ketrampilan proses sains bergantung kepada kemampuan peserta didik dalam hal mengasimilasikan suatu informasi atau konsep yang diberikan oleh guru melalui kegiatan mendengarkan, mengamati dan mencatat. Jadi model pengajaran langsung kurang memberikan kesempatan peserta didik untuk terlibat dalam menemukan dan membentuk konsepnya. Berdasarkan teori tersebut, secara deskriptif penelitian ini juga menunjukkan bahwa terdapat perbedaan keterampilan proses sains antara kelompok model pembelajaran inkuiri terbimbing dengan model pengajaran langsung.

Hal ini dapat dilihat dari perolehan skor rata-rata keterampilan proses sains pada kelompok model pembelajaran inkuiri terbimbing memiliki skor rata-rata post test sebesar 81,44 dan standar deviasi 8,26, sedangkan untuk kelompok model pengajaran langsung skor rata-rata post test sebesar 75,76 dan standar deviasinya 8,78 . Skor rata-rata keterampilan proses sains setelah dibelajarkan dengan model pembelajaran inkuiri terbimbing lebih tinggi dibandingkan dengan dibelajarkan dengan model pengajaran langsung.

Terakhir adalah menganalisis perbedaan karakter siswa antara kelompok siswa yang dibelajarkan dengan model pembelajaran inkuiri terbimbing dan model pengajaran langsung. Secara statistik bahwa terdapat perbedaan karakter siswa yang signifikan antara model pembelajaran inkuiri terbimbing dan model pengajaran langsung. Sebagai tindak lanjut dari pengujian hipotesis ketiga, selanjutnya dilakukan analisis signifikansi perbedaa skor rata-rata karakter siswa antra kelompok model pemebelajaran inkuiri terbimbing dan model pengajaran langsung dengan menggunakan uji Least Significant Difference (LSD). Hasil analisis lanjutan menunjukkan terdapat perbedaan nilai rata-rata karakter siswa model pembelajaran inkuiri 
terbimbing dan model pengajaran langsung adalah nilai rata-rata karakter siswa antara kelompok model pembelajaran inkuiri terbimbing dan model pengajaran langsung berbeda secara signifikan pata taraf signifikansi 0,05 . Hasil analisis secara deskriptif juga menunjukkan bahwa terdapat perbedaan karakter siswa antara kelompok model pembelajaran inkuiri terbimbing dan model pengajaran langsung. Pada kelompok model pembelajaran inkuiri terbimbing nilai skor rata-rata karakter siswa 3,29 dengan standar deviasi 0,32. Kelompok model pengajaran langsung nilai skor rata-rata karakter siswa sebesar 3,08 dengan standar deviasi 0,36 . Skor rata-rata karakter siswa pada kelompok model pemebelajaran inkuiri terbimbing apabila di konversikan, maka berada pada

Penelitian ini perbedaan karakter siswa antara klompok model pembelajaran inkuiri terbimbing dan kelompok model pengajaran langsung dapat juga dilihat dari pencapaian setiap dimensi karakter siswa yang dinilai. Hasil Penelitian yang dilakukan oleh Miftakhul (2012) juga menunjukkan dengan inkuiri terbimbing dapat mempengaruhi peningkatan aspek karakter yang dinilai pada setiap pertemuannya.

Berdasarkan hasil penelitian, maka dapat dilihat bahwa terdapat perbedaan antara pencapaian setiap dimensi karakter siswa antara kelompok yang dibelajarkan dengan model pembelajaran inkuiri terbimbing dan model pengajaran langsung. Jika dibandingkan skor pencapaian setiap dimensi karakter siswa yang dibelajarkan dengan model pembelajaran inkuiri terbimbing lebih baik dibandingkan dengan skor pencapaian setiap dimensi model pengajaran langsung. Hal ini juga didukung oleh Sadia (2014) yang menyatakan keterlibatan siswa dalam kegiatan kegiatan inkuiri akan memberikan kesempatan kepada individu-individu siswa untuk memupuk rasa tanggung jawab, mengembangkan kreativitas, memupuk kejujuran, menumbuhkan rasa ingin tahu, menumbuh kembangkan rasa percaya diri. Bebeda halnya dengan model pengajaran langsung yang pondasi pembelajarannya lebih berorientassi kepada guru.

\section{Simpulan dan Saran}

Terdapat perbedaan keterampilan proses sains dan karakter siswa anatara kelompok model pemebalajaran inkuiri terbimbing dan model pengajaran langsung. Dengan nilai $F$ sebesar 1,114 dengan taraf signifikasi 0,000 yang berarti $p<0,05$. Terdapat perbedaan kterampilan proses sains antara siswa yang belajar dengan model pembelajaran inkuiri terbimbing dan model pengajaran langsung dengan nilai $F=8,443$ dengan nilai signifikasi 0,005 , dimana $p<0,05$. Berdasarkan uji LSD, diperoleh hasil 5,684 nilai signifikansi 0,005 yang lebih kecil dari 0,05. Skor LSD yaitu 3,4. Jadi dapat dikatakan keterampilan proses sains siswa kelompok model pembelajaran inkuiri terbimbing dan model pengajaran langsung berbeda secara signifikan. Terdapat perbedaan karakter siswa kelompok model pembelajaran inkuiri terbimbing dan model pengajaran langsung dengan nilai $F$ sebesar 223,287 dan memiliki nilai signifikansi 0,000 atau $P<0,05$. Berdasarkan uji lanjutan dengan LSD, hasil diperoleh sebesar 0,0703 dan nilai signifikansinya sebesar 0,000 yang lebih kecil dari 0,05. Skor LSD yaitu 0,08. Jadi karakter siswa kelompok model pembelajaran inkuiri terbimbing dan model pengajaran langsung berbeda secara signifikan.

Model pembelajaran inkuiri terbimbing memiliki pengaruh yang signifikan terhadap keterampilan proses sains dan karakter siswa. Dengan demikian guru bisa mengaplikasikan model pembelajaran inkuiri terbimbing dalam pembelajaran di kelas. Penelitian ini hanya dilakukan pada pokok bahasan ekosistem dan pemanasan global saja, sehingga penulis menyarankan kepada peneliti lain untuk menggunakan model pembelajaran inkuiri terbimbing pada pokok bahasam terutama disiplin IImu Pengetahuan Alam, karena model ini berlandasan konstrutivisme oleh karena itu sangat cocok diterampakan dalam pembelajaran untuk membangun konsep pada peserta didik.

\section{Daftar Pustaka}

Akhlis, I. N., R. Dewi. 2014. "Perangkat pembelajaran Science Berorientasi Cultural Deviance Solution Berbasis Inkuiri Menggunakan Ict Untuk Mengembangkan Karakter Peserta Didik", Jurnal Pendidikan IPA, 3(1), 86-94.

Arnyana, I. B. P. 2011. Buku Ajar Strategi Belajar Mengajar. Singaraja: Jurusan Pendidikan Biologi Fakultas MIPA. Universitas Pendidikan Ganesha. 
IVCEJ, Vol 1 No 1 , Tahun 2018

p-ISSN: 2615-4684 e-ISSN: 2615-6938

Ambarsari, W, S, Santosa, Maridi. 2013. "Penerapan Pembelajaran Inkuiri Terbimbing Terhadap Keterampilan Proses Sains Dasar Pada Pelajaran Biologi Siswa Kelas Viii Smp Negeri 7 Surakarta", Jurnal Pendidikan Biologi, 5(1), 81-95.

Dimyati \& Mudjiono, 2015, Belajar dan Pembelajaran, Jakarta: PT Rineka Cipta

Hermawati, M. N. W. 2012. Pengaruh Model Pembelajaran Inkuiri Terhadap Penguasaan Konsep Biologi danS ikap IImiah Siswa SMA Ditinjau Dari Minat Belajar Siswa. Artikel. Pasca Sarjana Universitas Pendidikan Ganesha.

Khusniati, M. 2014. "Model Pembelajaran Sains Berbasis Kearifan Lokal Dalam Menumbuhkan Karakter Konservasi". Indonesian Journal of Conservation. 3(1), ISSN: 2252-9195.

Miftakhul, J. Sugianto \& Sarwi. 2012. "Pengembangan Perangkat Pembelajaran Berorientasi Nilai Karakter Melalui Inkuiri Terbimbing Materi Cahaya Pada Siswa Kelas Viii Sekolah Menengah Pertama". Journal of Innovative Science Education. 1(1). ISSN 2252 - 6412.

Nurohman, S. 2010. Penerapan Seven Jump Method (SJM) Sebagai Upaya Peningkatan Keterampilan Proses Sains Mahasiswa. Yogyakarta: FMIPA Universitas Negeri Yogyakarta.

Sadia, I. W. 2014. Model-Model Pembelajaran Sains Konstruktivistik, Yogyakarta: Graha Imu.

Sugiyono, 2014. Metode Penelitian Kuantitatif Kualitatif Dan R \& D. Bandung: Alfbeta.

Suwandri, H. N. M. 2015. Pengaruh Model Discovery Learning Terhadap Keterampilan Proses Sains dan Sikap IImiah Pada Mata Pelajaran IPA Siswa SMP. Tesis. Pasca Sarjana Universitas Pendidikan Ganesha.

Undang-undang Nomor 20 Tahun 2003. tentang Sistem Pendidikan Nasional.

Warianto, C. 2011. Biologi sebagai ilmu. Makalah. Online. Diakses 9 Juni 2015.

Wagiran. 2011. Pengembangan Karakter Berbasis Kearifan Lokal Hamemayu Hayuning Bawana (Identifikasi Nilai-Nilai Karakter Berbasis Budaya), Jurnal Pendidikan Karakter, 2 (3).

Yuniastuti. E. 2013, "Peningkatan Ketrampilan Proses, Motivasi, Dan Hasil Belajar Biologi Dengan Strategi Pembelajaran Inkuiri Terbimbing Pada Siswa Kelas VII SMP Kartika V1 Balikpapan". Jurnal Penelitian Pendidikan.14(1). 